\title{
SIFAT KEILMUAN ANTROPOLOGI HUKUM
}

\section{Ossandra Dwi Putri}

\section{Email: ossandradp@gmail.com}

\section{No BP: 2010003600152}

\section{Universitas Ekasakti}

\section{A. PENDAHULUAN}

Antropologi hukum merupakan cabang ilmu pengetahuan hukum yang mempelajari pola-pola sengketa dan penyelesaiannya, baik pada masyarakat yang sederhana maupun pada masyarakat yang mengalami modernisasi. Antropologi hukum merupakan realitas atau kenyataan atas kehidupan hukum yang sesungguhnya berjalan dan hidup di masyarakat.

Pendekatan yang digunakan Antropologi Hukum dalam mengkaji hukum adalah menggunakan pendekatan Holistik (menyeluruh) terhadap seluruh aspek kehidupan manusia antara lain hukum, ekonomi, politik, termasuk budaya. Definisi yang dapat diterima Antropologi Hukum adalah rumusan dari Hoebel yakni suatu norma sosial adalah hukum. Bila terjadi pelanggaran atau tindakan tidak mengindahkan norma sosial maka yang melanggar akan diberikan sanksi, baik dalam bentuk sanksi tindakan fisik, diberikan sanksi sosial dan sanksi yang lainnya oleh yang mempunyai wewenang bertindak.

\section{B. PEMBAHASAN}

1. Antropologi hukum tidak membatasi pandangan pada kebudayaan tertentu (studi perbandingan).

Masyarakat manusia dipelajari dengan cara perbandingan. Bagaimana sederhananya tahap perkembangan masyarakat, seperti terhadap 
perkembangan masyarakat, sepatutnya dipelajari di samping masyarakat yang budayanya sudah maju, yang tidak dibedakan secara kualitatif. Harus disadari bahwa hukum lahir dan berkembang dari sebuah kebudayaan, sehingga akan menjadi logis bahwa tidak ada hukum yang seragam, karena tidak ada kebudayaan yang bersifat seragam.

Hukum yang berlaku bagi masyarakat dalam suku yang lain dan untuk negara yang seluas dan sebesar Indonesia, tentu apabila diberlakukan hukum secara seragam terhadap masyarakat yang memiliki beragam kebudayaan bisa menimbulkan masalah keadilan. Dalam perspektif Antropologi, hukum lahir dari kebudayaan melihat hal tersebut, menyadarkan kepada kita bahwa peran Antropologi hukum adalah perspektif untuk melihat berbagai macam corak hukum dan ragam kebudayaan.

2. Antropologi Hukum mempelajari masyarakat sebagai suatu keseluruhan yang utuh, dimana bagian-bagiannya saling bertautan.

Antropologi hukum berbeda dari cabang ilmu sosial yang lain karena ilmu ini mempelajari masyarakat sebagai keseluruhan yang uttuh dimana bagian-bagiannya saling bertautan. Jadi tidak dipotong menurut sesi-sesi tertentu misalnya segi ekonomi, segi politik dan segi hukum sebagai sesi tersendiri.

3. Antropologi Hukum modern tidak memusatkan perhatian hanya pada kekuatan soisal dan hal super organis.

Antropologi hukum yang modern tidak lagi memusatkan perhatiannya pada kekuatan-kekuatan sosial dan hal-hal yang super organis. Lalu 
memperkecil peranan imdividu. Kesemuaannya mendapatkan perhatian yang sama.

4. Antropologi Hukum memandang masyarakat secara dinamis, sehingga peranan sosial dan hukum tidak terbatas mempertahankan status quo.

Antropologi hukum tidak memandang masyarakat yang dalam keseimbangan yang mengalami gangguan jika ada penyimpangan, tetapi masyarakat dipandang secara dinamis, sehingga peranan sosial dalam hukum tidak terbatas mempertahankan status quo. Sebagaimana Stone mengemukakan antropologi hukum bukanlah penganut ketidakmampuan legislatif.

5. Antropologi Hukum termasuk ilmu hukum yang empitis

Konsekuensinya ialah bahwa teori yang dikemukakan harus didukumg oleh fakta yang relevan atau setidak-tidaknya terwakili secara representatif dari fakta yang relevan.

\section{PENUTUP}

Berdasarkan pembahasan diatas, dapat ditarik kesimpulan sebagi berikut: Sifat Keilmuan Antropologi Hukum

1. Antropologi hukum tidak membatasi pandangan pada kebudayaan tertentu (studi perbandingan) 
2. Antropologi hukum mempelajari sebagai suatu keseluruhan yang utuh dimana bagian-bagiannya saling bertautan.

3. Antropologi hukum modern tidak memusatkan perhatian hanya pada kekuatan sosial dan hal super organis.

4. Antropologi hukum memandang masyarakat secara dinamis sehingga peranan sosial dan hukum tidak terbatas mempertahankan status hukum.

5. Antropologi hukum termasuk ke dalam ilmu hukum yang empiris.

\section{DAFTAR PUSTAKA}

Gokma Toni Parlindungan S, Asas Nebis In Idem Dalam Putusan Hakim Dalam Perkara Poligami Di Pengadilan Negeri Pasaman Sebagai Ceriminan Ius Constitutum, Volume 2, Nomor 1, 2020.

Gokma Toni Parlindungan S, Pengisian Jabatan Perangkat Nagari Pemekaran Di Pasaman Barat Dalam Rangka Pelaksanaan Otonomi Daerah, Ensiklopedia Of Journal, Vol 1 No 2 Edisi 2 Januari 2019,

Harniwati, Peralihan Hak Ulayat Menurut Undang-Undang Nomor 18 Tahun 2004, Volume 1, Nomor 3, 2019.

Jasmir, Pengembalian Status Hukum Tanah Ulayat Atas Hak Guna Usaha, Soumatera Law Review, Volume 1, Nomor 1, 2018. 
Jumrawarsi Jumrawarsi, Neviyarni Suhaili, Peran Seorang Guru Dalam Menciptakan Lingkungan Belajar Yang Kondusif, Ensikopedia Education Review, Vol 2, No 3 (2020): Volume 2 No.3 Desember 2020

Mia Siratni, Proses Perkawinan Menurut Hukum Adatdi Kepulauan Mentawai Di Sebelum Dan Sesudah Berlakunya Undang-Undang Nomor 1 Tahun 1974 Tentang Perkawinan, Ensiklopedia Of Journal, Vol 1 No 2 Edisi 2 Januari 2019,

Remincel, Dimensi Hukum Pelanggaran Kecelakaan Lalu Dan Angkutan Jalan Lintas Di Indonesia, Ensiklopedia Social Review, Volume 1, Nomor 2, 2019.

R Amin, B Nurdin, Konflik Perwakafan Tanah Muhammadiyah di Nagari Singkarak Kabupaten Solok Indonesia 2015-2019, Soumatera Law Review, Volume 3, Nomor 1, 2020. 